\title{
Respiratory Failure in Covid19 is associated with increased monocyte expression of complement receptor 3
}

\author{
Rajeev Gupta ${ }^{1,2^{*}}$, Vanya Alasdair ${ }^{3^{*}}$ Gant, Bryan Williams ${ }^{4}$ and Tariq Enver ${ }^{1}$ \\ ${ }^{1}$ Stem Cell Group, UCL Cancer Institute, University College London, London, WC1E 6BT, UK. ${ }^{2}$ Manual Blood \\ Sciences, Health Services Laboratories, The Halo Building, 1 Mabledon Place, London WC1H 9AX, UK. \\ Departments of ${ }^{3}$ Microbiology and ${ }^{4}$ Medicine UCLH NHS Hospitals Foundation Trust, 250 Euston Road, London \\ NW1 2 PG, UK NW1 2 PG *Corresponding Authors
}

A key question in COVID-19 infection is why some previously healthy patients develop severe pulmonary failure and some ultimately die. Initial pulmonary failure does not exhibit classical features of ARDS; hypercoagulability is a common laboratory finding, and pulmonary thrombotic microangiopathy has been reported post mortem ${ }^{1,2,3}$. Biomarkers cannot robustly identify such patients pre-emptively and no specific interventions exist to mitigate clinical deterioration. Mononuclear phagocytic cells are key immune cells and bind fibrinogen through the CD11b/CD18 dimer CR3, whose activated form can initiate microthrombus formation. Accordingly, we profiled circulating monocyte CD11b/CD18 cell surface density from COVID-19 infected adults who were (i) symptomatic but breathless, (ii) requiring ventilatory support, and (iii) recovering following ICU care for hypoxia.

\section{Methods}

We repurposed a multiparameter flow cytometry assay, used routinely in our institution for the diagnosis of leukaemia, to measure the cell surface expression density of CD11b and CD18 in peripheral blood monocytes from three clinically distinct groups of COVID19 patients (29 in total), and compared them to non-COVID19 patients requiring ventilatory support, with the historical group of healthy controls used for initial test calibration as reference. Analysis was performed using surplus material from routine CBC specimens. Sample preparation was with the TQ-Prep whole blood lysis system (Beckman Coulter), and antibody staining was with a Duraclone lyophilised antibody panel (B38683, Beckman Coulter, Table 1). A minimum of 50000 events were collected: monocytes were defined as $\mathrm{CD}_{4} 5^{+} \mathrm{CD} 13^{+} \mathrm{CD} 33^{++} \mathrm{CD} 15^{+-} \mathrm{SSc}{ }^{\text {int }}$ cells. The expression level of each antigen was calculated as its corrected Mean Fluorescence Intensity (MFI): [raw value arithmetic mean fluorescence in monocytes - raw value arithmetic mean fluorescence in $\mathrm{CD} 5^{++} \mathrm{CD}^{+} \mathrm{CD} 56-\mathrm{SSc}^{10} \mathrm{~T}$ cells]. We defined "hypoxic" patients as requiring ICU Level 3 ventilatory support within 15 days of a PCR diagnosis of SARS-CoV2 infection; "convalescing" as having recovered following ICU care for COVID with minimal or absent oxygen requirements, but at least 30 days from initial diagnosis; and "well" as having mild symptoms prompting a positive PCR test within the previous 10 days, but who were neither ever breathless nor hospitalised. No patient in this study had a prior history of malignancy or immunosuppression. 
medRxiv preprint doi: https://doi.org/10.1101/2020.05.31.20118638; this version posted June 2, 2020. The copyright holder for this preprint

(which was not certified by peer review) is the author/funder, who has granted medRxiv a license to display the preprint in perpetuity.

It is made available under a CC-BY-NC-ND 4.0 International license .

\section{Results}

Table 2 shows clinical and haematological parameters and Figure 1 the levels of monocyte CD11b and CD18 for each COVID-19 group and the two non-COVID-19 cohorts. CBC parameters were not significantly different, however expression of both CD11b and CD18 was higher in COVID-19 patients who were hypoxic requiring respiratory support. Convalescing patients had intermediate levels of CD11b, but CD18 had returned to normal. Levels were not elevated in patients who had SARSCoV2 infection but remained well, and those requiring ventilatory support for reasons other than COVID-19. Consistent with others, we found that hypoxic COVID-19 patients had lymphopenia, but this was also seen in non-COVID hypoxic patients, and likely represents a stress response.

\section{Discussion}

Monocytes mediate initial immune responses to pathogens, induce inflammation following tissue damage and regulate haemostasis at sites of injury ${ }^{4}$. CD11b and CD18, which together constitute Complement Receptor 3 (CR3) are key to this ${ }^{5}$. We demonstrate that monocyte CR3 is significantly increased in COVID-19 patients with hypoxia compared with those without respiratory symptoms and non-COVID hypoxic patients. This hitherto unappreciated observation tables monocyte activation as a biomarker for respiratory complications in COVID-19, possibly by driving thrombotic microangiopathy due to increased binding of fibrinogen. Although adaptive immune responses to SARS-CoV2 determine subsequent immunity, innate immune responses dictate the early clinical course, and our findings encourage serial tracking of monocyte CR3 expression in individual patients with COVID-19. CR3 may be targeted therapeutically; both non-specifically by early anticoagulation, or directly using several licensed drugs ${ }^{5}$. Such approaches may reduce the likelihood of respiratory failure and could inform a preventative approach to the management of COVID19- mediated respiratory failure in the future.

\section{References}

1. Richardson S, Hirsch JS, Narasimhan M, et al. Presenting Characteristics, Comorbidities, and Outcomes Among 5700 Patients Hospitalized With COVID-19 in the New York City Area

JAMA. Published online April 22, 2020. doi:10.1001/jama.2020.6775

2. Varga Z, Flammer AJ, Steiger $P$, et al Endothelial cell infection and endotheliitis in COVID-19. Lancet Published online April 17, 2020 https://doi.org/10.1016/S01406736(20)30937-5

3. Magro C,,Mulvery JJ, Berlin D, et al. 
Complement associated microvascular injury and thrombosis in the pathogenesis of severe COVID-19 infection: A report of five cases, Translational Research (2020), doi: https://doi.org/10.1016/j.trsl.2020.04.007

4. Class CK and Natoli G. Molecular control of activation and priming in macrophages. Nature Immunology 2016; 17:26-33

5. Vorup-Jensen $\mathrm{T}$ and Jensen RK. Structural Immunology of Complement Receptors 3 and 4. Front. Immunol. 2018; 9:2716.

\section{Author Contributions:}

RG and VAG had full access to all the data in the study and take responsibility for the integrity of the data and the accuracy of the data analysis.

Concept and design: RG, VAG, TE

Acquisition, analysis, or interpretation of data: All authors

Drafting of the manuscript: RG, VAG

Critical revision of the manuscript for important intellectual content: All authors

Administrative, technical, or material support: All authors

Supervision: All authors

Conflict of Interest Disclosures: Dr Gant reported receiving personal fees from Gilead and Bio Mérieux

Funding/Support: The study was funded by UCL Biomedical Research Centre's emergencyCOVID-19 funds and Blood Cancer UK. We are also extremely grateful to Sir Peter Woodfor his philanthropic donation towards essential Research laboratory equipment.

Role of the Funder/Sponsor: Facilitated study logistics and reagents 
Table 1

\begin{tabular}{|c|c|c|c|c|c|c|c|c|c|c|}
\hline Antigen & CDR & cDAtb & CDis & CD15 & cota & $\cos$ & $\cos 4$ & CD45 & COE6 & CD117 \\
\hline Clone & 3901.5 & Bear1 & $\begin{array}{c}\text { Immu103 } \\
.44\end{array}$ & 80H5 & $\pi$ 4 & $\begin{array}{c}\text { D3HL60.2 } \\
51\end{array}$ & 581 & $\mathbf{1 3 3}$ & Na01 & 104D2D1 \\
\hline $\begin{array}{l}\text { Fluoro- } \\
\text { chrome }\end{array}$ & $\begin{array}{l}\text { APC- } \\
\text { a750 }\end{array}$ & FITC & PC5.5 & PB & PE & PC7 & ECD & Kro & $\begin{array}{l}\text { APC- } \\
\text { A700 }\end{array}$ & APC \\
\hline
\end{tabular}

Antigen specificities with respective clone identities and fluorochromes in the Duraclone B38683 antibody panel

Table 2

\begin{tabular}{|c|c|c|c|c|c|}
\hline $\begin{array}{l}\text { Parametar } \\
\text { (normal range) }\end{array}$ & & $\begin{array}{c}\text { COMD } \\
\text { "wall" } \\
n=11\end{array}$ & $\begin{array}{c}\text { covid } \\
\text { "hypoxle" } \\
n=10\end{array}$ & $\begin{array}{c}\text { COMD } \\
\text { "comvaleseing" } \\
n=8\end{array}$ & $\begin{array}{c}\text { Non-COND } \\
\text { "hypoxde" } \\
n=5\end{array}$ \\
\hline $\begin{array}{l}\text { Total WCC } \\
\text { Ra-10.a rtosy }\end{array}$ & maan & 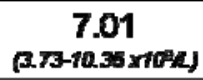 & $\begin{array}{c}7.00 \\
(201-1313 \times 100 \mathrm{R})\end{array}$ & $\begin{array}{c}8.54 \\
\text { F.01-14.31 } \times 1004,4\end{array}$ & 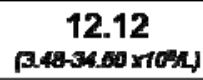 \\
\hline $\begin{array}{l}\text { Monocyfes } \\
\text { (a.1-1.0.10il) }\end{array}$ & maan & $\begin{array}{c}0.54 \\
\text { (a.320.84 xtas) }\end{array}$ & $\begin{array}{c}0.35 \\
(2.13-0.63 \times 700)\end{array}$ & $\begin{array}{c}0.54 \\
\text { a.17-1.2001004 }\end{array}$ & $\begin{array}{c}0.56 \\
\text { (a.26-1.00 rtant }\end{array}$ \\
\hline $\begin{array}{c}\mathrm{CDS}^{+} 4+\mathrm{T} \text { colls } \\
\text { (2.48-1.64 nolf }\end{array}$ & $\begin{array}{c}\text { mogin } \\
\text { rase }\end{array}$ & $\begin{array}{c}0.80 \\
(0.43-1.51 \times 70(1)) \\
\end{array}$ & 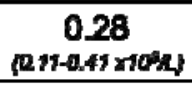 & $\begin{array}{c}0.74 \\
(0-35-1.87 \times 104) \\
\end{array}$ & 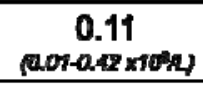 \\
\hline $\begin{array}{c}C D 3^{+} g^{+} T \text { cells } \\
0.21-1.09 \text { xtofl }\end{array}$ & $\begin{array}{c}\text { mogin } \\
\text { rage }\end{array}$ & $\begin{array}{c}0.46 \\
(0.18-0.95 \times 10 \%)\end{array}$ & $\begin{array}{c}0.10 \\
(0.02-0.22 \times 10 \%)\end{array}$ & $\begin{array}{c}0.18 \\
\text { (a.00-ass } \times 100)\end{array}$ & $\begin{array}{c}0.24 \\
(0.07-0.97 \times 70 \%)\end{array}$ \\
\hline$\underset{(136-226 \mathrm{rU})}{L D H}$ & mean & 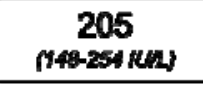 & $\begin{array}{c}400 \\
\text { pse-ser nus }\end{array}$ & $\begin{array}{c}380 \\
\text { (205-563 RUL }\end{array}$ & $\begin{array}{c}312 \\
\text { (109-578 (KL) }\end{array}$ \\
\hline $\begin{array}{l}\text { D-Dimer } \\
\text { (0-550 pol) }\end{array}$ & mean & $\begin{array}{c}887 \\
(190-6260 \text { wot })\end{array}$ & $\begin{array}{c}4128 \\
\text { (810-17070 peL }\end{array}$ & 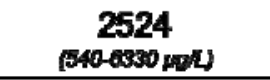 & not available \\
\hline
\end{tabular}

Laboratory parameters of patient groups. COVID "hypoxic", COVID "convalescing" and non-COVID "hypoxic" cohorts had significantly lower $\mathrm{CD}^{+} 4^{+}$and $\mathrm{CD}^{+} 8^{+} \mathrm{T}$ cell counts, and significantly higher serum LDH levels than the COVID "well" group $(p<0.05)$. The difference in D-Dimer between the three COVID groups was not significant. 
Figure 1

$\underline{\text { CD11b }}$

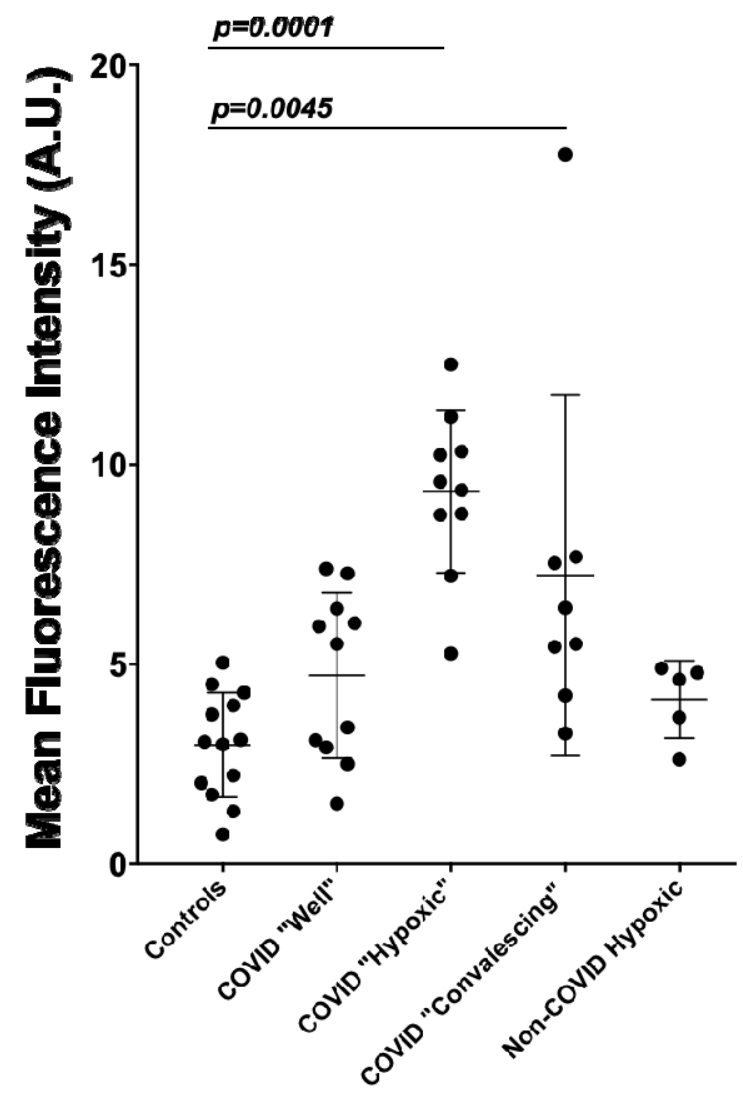

$\underline{\text { CD18 }}$

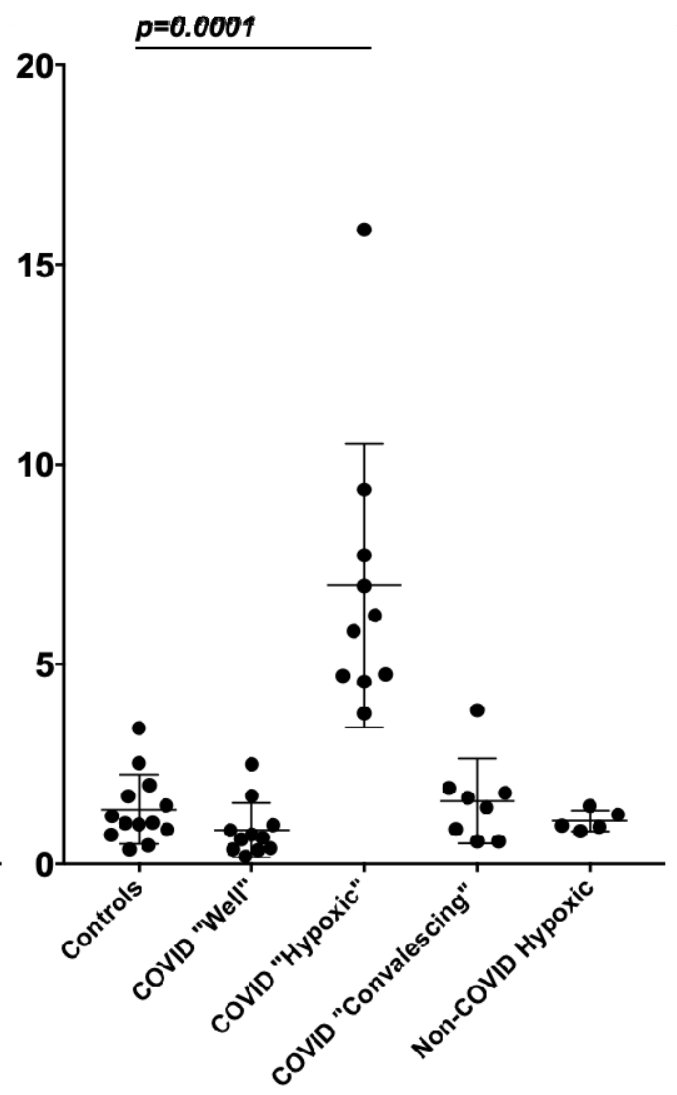

Mean Fluorescence intensity of CD11b and CD18 expression (Arbitrary Units) in peripheral blood monocytes. Controls are the historical cohort of healthy volunteers with normal blood counts used for validation of the assay. Horizontal bars indicate groups with significantly different expression levels and relevant $p$ values. 